\title{
PERSENTASE TUTUPAN TERUMBU KARANG DI PERAIRAN PASIR PUTIH KABUPATEN MANOKWARI
}

\author{
Percent Cover Coral Reef at Pasir Putih Waters in Manokwari Regency \\ Adi Ivandi Thovyan ${ }^{1}$, Vera Sabariah ${ }^{1 *}$, Dedi Parenden ${ }^{1}$ \\ ${ }^{1}$ Jurusan Perikanan, FPIK UNIPA, Manokwari, 98314, Indonesia \\ *korespondensi : vsabariah@yahoo.com
}

\begin{abstract}
ABSTRAK
Penelitian ini dilakukan pada bulan Oktober sampai November 2014 di perairan Pasir Putih Kabupaten Manokwari, berlokasi di Pantai Air Salobar. Tujuan penelitian adalah untuk mengetahui persentase tutupan terumbu karang, kualitas fisik-kimia air dan korelasi kualitas fisik-kimia air terhadap persentase tutupan terumbu karang di bagian barat daya perairan Pasir Putih, Manokwari. Metode yang digunakan untuk memperoleh data persentase tutupan karang adalah Point Intercept Transect (PIT) pada kedalaman $3 \mathrm{~m}$ (Transek I), $7 \mathrm{~m}$ (Transek II) dan $10 \mathrm{~m}$ (Transek III). Hasil pengamatan diperoleh persentase tutupan karang pada Transek I adalah 91\%, Transek II adalah 78\% dan Transek III adalah 54\%. Kondisi terumbu karang di perairan Pasir Putih berada dalam kondisi baik hingga sangat baik. Kondisi sangat baik terdapat pada Transek I dan II, sedangkan kondisi baik terdapat pada Transek III. Bentuk pertumbuhan yang paling dominan pada Transek I dan III adalah coral branching. Persentase tutupan coral branching pada Transek I adalah 59\% dan Transek III adalah 20\%. Bentuk pertumbuhan Coral Branching yang ditemukan, didominasi oleh karang dari genus Montipora dan Psammocora. Untuk genus Montipora yang ditemukan adalah spesies Montipora digitata. Sedangkan dari genus Psammocora yang ditemukan adalah spesies Psammocora contigua. Sedangkan bentuk petumbuhan yang paling dominan pada Transek II adalah Coral Encrusting (28\%). Kualitas fisik-kimia air yang diukur pada perairan Pasir Putih adalah suhu $27,5-29^{\circ} \mathrm{C}$, Oksigen terlarut 5,08-5,2 ppm, pH 7,03-7,15, salinitas 30-31\%, kecepatan arus 0,08 m/s dan kecerahan perairan 16 m. Nilai kualitas fisik-kimia air ini termasuk ideal bagi pertumbuhan terumbu karang. Hasil uji korelasi menunjukkan bahwa parameter kualitas air yang paling berpengaruh atau sangat signifikan $(\rho=0,01)$ terhadap persentase tutupan karang adalah suhu, oksigen terlarut dan kedalaman perairan.
\end{abstract}

Kata Kunci: Perairan Pasir Putih, Persentase Tutupan, Parameter Fisik-Kimia Air, Uji Korelasi

\begin{abstract}
This research was done on October-November 2014 at Pasir Putih coastal area of Manokwari Regency and located at Air Salobar beach. The research aimed to know percent cover of coral reef, physical and chemical water quality, also the correlation of water quality to coral reef percent cover at southern west part of Pasir Putih coast in Manokwari. The method used in this study was Point Intercept Transect (PIT) at the depth of $3 \mathrm{~m}$ (Transect I), $7 \mathrm{~m}$ (Transect II) dan $10 \mathrm{~m}$ (Transect III) to determine coral reef. Results showed that percent cover of coral reef on Transect I was 91\%, Transect II 78\% amd Transect III 54\%. Coral reef condition in Pasir Putih coast was in good to very good status. Very good confition was in Transecr I and II, whereas good condition on Transect III. Dominant lifeform of growth on Transect I and III was coral branching. The percentage cover of coral branching on Transect I was 59\% and Transect III was $20 \%$. Lifeform growth of coral branching found was dominated by coral genus Montipora and
\end{abstract}


Psammocora. Genus Montipora on this area was spesies Montipora digitata. On the other hand, genus Psammocora found in the same location was spesies Psammocora contigua. Moreover, dominant lifeform of growth on Transect II was Coral Encrusting (28\%). Physical chemical quality of sea-water in Pasir Putih consisted of temperature $27,5-29^{\circ} \mathrm{C}$, dissolved oxigen 5,08-5,2 ppm, $\mathrm{pH} 7,03-7,15$, salinity 30-31\%, current $0,08 \mathrm{~m} / \mathrm{s}$ and clearness $16 \mathrm{~m}$. These grades of physical chemical quality of sea-water was ideal to the growth of coral reef. Correlation of water quality parameter that has most siginificant effect $(\rho=0,01)$ to coral reef percent cover was temperature, dissolved oxygen and water depth.

Key words: Pasir Putih Beach, Percent Cover, Physical Chemical parameter, Correlation test.

\section{PENDAHULUAN}

Salah satu pusat sebaran terumbu karang dunia berada di Indonesia dengan luas diperkirakan sekitar $85.700 \mathrm{~km}^{2}$ atau sekitar $14 \%$ dari total sebaran karang dunia (Burke et al, 2002 dalam Pasanea, 2013). Dari seluruh lokasi sebaran terumbu karang di Indonesia, sebagian besar dalam kategori rusak. Rata-rata tutupan karang hidup yang kondisinya masih sangat baik dan baik hanya sekitar 5,5\% dan $27 \%$. Selebihnya dalam kondisi yang kurang baik dan buruk yakni masingmasing 36,5\% dan 33\% (LIPI, 2009 dalam Burhanuddin $d k k$, 2013). Rusaknya terumbu karang sebagai akibat pemanfaatan sumberdaya laut yang menggunakan cara yang tidak ramah lingkungan, seperti penggunaan bahan peledak dan penggunaan racun (potasium sianida) yang tidak hanya merusak populasi ikan tetapi juga memusnahkan habitatnya (terumbu karang), penangkapan yang berlebihan (over fishing) dari stok yang ada, serta proses sedimentasi dan pencemaran.

Pantai Yen beba atau yang lebih dikenal dengan nama Pasir Putih adalah salah satu lokasi wisata di kawasan Teluk Doreri di Kabupaten Manokwari. Perairan Pasir Putih masuk dalam wilayah perairan Teluk. Lokasi ini dapat dica-pai dari pusat kota Manokwari dengan meng-gunakan kendaraan bermotor sekitar \pm 15 menit.

Pasir Putih cukup mendapat banyak perhatian masyarakat di Kota Manokwari, karena menjadi salah satu tujuan wisata yang terkenal di Kabupaten Manokwari. Namun, ekosistem terumbu karang pada perairan tersebut dikhawatirkan telah mengalami degradasi. Hal ini dikarenakan aktivitas masyarakat setempat yang meletakkan jangkar perahu pada daerah terumbu karang dan aktivitas wisatawan yang secara langsung menginjak karang yang berpengaruh terhadap menurunnya persen tutupan karang dan pengelolaan sumberdaya ini di kemudian hari.

Penelitian ini bertujuan untuk mengetahui persentase tutupan terumbu karang di Perairan Pasir Putih Manokwari dan mengetahui kualitas fisik-kimia air dan korelasinya terhadap persentase tutupan terumbu karang di Perairan Pasir Putih, Manokwari.

\section{METODE PENELITIAN}

Penelitian ini dilaksanakan pada bulan Oktober sampai November tahun 2014. Lokasi penelitian bertempat pada perairan Pasir Putih Kabupaten Manokwari Provinsi Papua Barat (Gambar 1).

Pengambilan data persen tutupan karang dilakukan dengan metode PIT (Point Intercept Transect) seperti yang dikemukakan oleh Hill and Wilkinson (2004). Panjang garis transek 50 meter yang ditarik sejajar atau secara ho-rizontal pada hamparan terumbu karang di titik pengamatan pada stasiun yang sudah ditentukan.

Penelitian ini menggunakan tiga Transek, yang masing-masing diletakkan pada kedalaman yang berbeda. Transek I diletakkan pada kedalaman $3 \mathrm{~m}$ dengan koordinat $134^{\circ} 06^{\prime} 19,94^{\prime \prime}$ BT dan $00^{\circ} 52$ '29,05' LS, Transek II diletakkan pada kedalaman $7 \mathrm{~m}$ dengan koordinat $134^{\circ} 06^{\prime}$ $20,41{ }^{\prime \prime}$ BT dan $00^{\circ} 52^{\prime} 29,19{ }^{\prime \prime}$ LS dan Transek III diletakkan pada kedalaman 10 
$\mathrm{m}$ dengan koordinat $134^{\circ} 06^{\prime} 21^{\prime \prime} \mathrm{BT}$ dan $00^{\circ} 52^{\prime} 29,3$ ' LS.

Penyelaman dilakukan oleh 2 orang penyelam yang bertugas untuk mengamati dan mencatat objek penelitian, mendokumentasikan kegiatan pengambilan data dan mem-bentangkan roll meter. Obyek yang diamati adalah setiap bentuk pertumbuhan karang yang dilewati oleh garis Transek. Obyek ter-sebut adalah karang keras (hard coral), karang lunak (soft coral), karang mati (death coral), alga, pasir (sand), fauna lain (others).
Pada pelaksanaannya, pengamat menyelam sepanjang transek dan mencatat segala kategori bentuk pertumbuhan (lifeform) di bawah meteran dimulai pada 0,5 meter dan berakhir pada 50 meter dengan interval 0,5 meter.

Pengukuran kualitas fisik-kimia air di-lakukan pada lokasi penelitian untuk mengetahui parameter kualitas air yang ada di lokasi penelitian. Parameter kualitas fisik-kimia air yang diukur adalah oksigen terlarut (DO), salinitas, derajat keasaman $(\mathrm{pH})$, suhu, kece-patan arus dan kecerahan perairan.

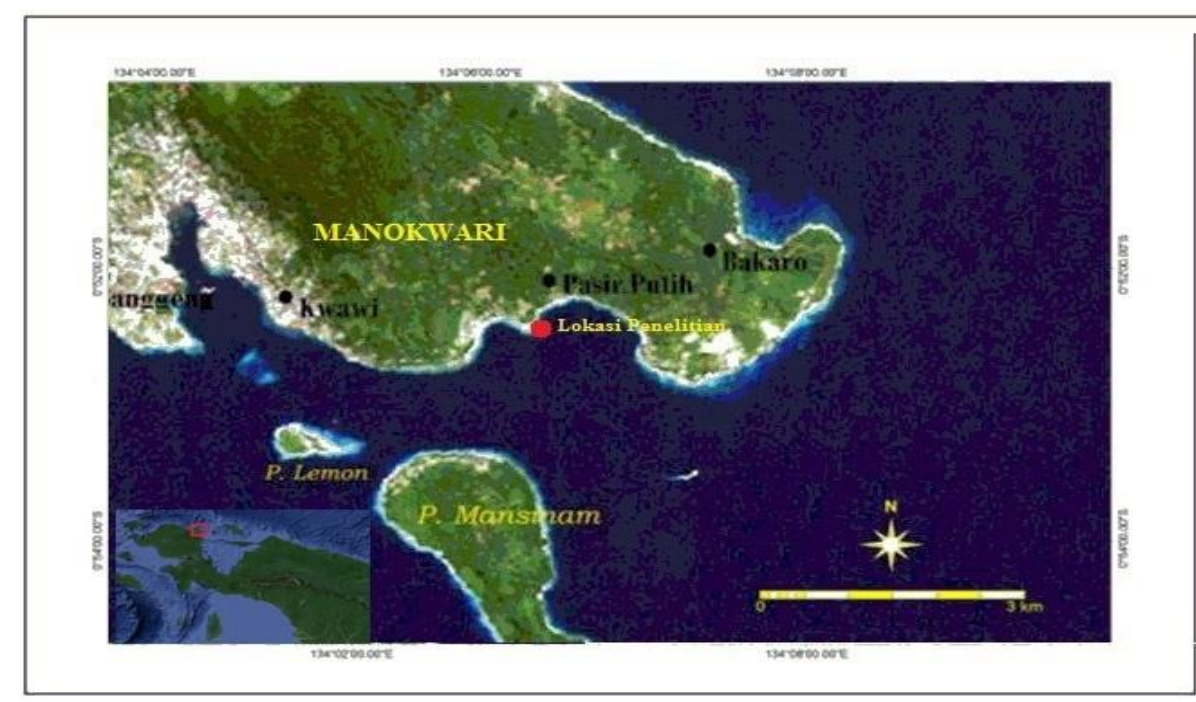

Gambar 1. Peta Lokasi Penelitian

Identifikasi bentuk pertumbuhan karang dilakukan dengan cara memperhatikan warna serta bentuk morfologi luar karang, meng-gunakan buku identifikasi English et al (1994). Beberapa jenis karang yang dominan di perairan, diidentifikasi menggunakan buku Coral of the World oleh Veron (2000).

Pengamatan kegiatan masyarakat di sekitar perairan Pasir Putih dan penelusuran dokumen terkait pemanfaatan maupun pengelolaan sumberdaya perairan ini di Kabupaten Manokwari dilakukan untuk menunjang tu-lisan. Analisis data yang dilakukan meliputi Persentase tutupan karang, dan analisis korelasi.

\section{Persentase Tutupan Karang}

Pengamatan bentuk pertumbuhan karang dengan metode PIT selanjutnya diolah dengan menggunakan Microsoft
Excel untuk menge-tahui persentase tutupan karang. Rumus persentase tutupan karang (Manuputty and Djuwariah, 2009) sebagai berikut:

$\mathrm{PC}=\frac{\text { Jumlah Titik Tiap Komponen }}{\text { Total Komponen }} \times 100 \%$

Dari hasil analisis tersebut, kemudian ditentukan kondisi terumbu atau tingkat kerusakan terumbu karang berdasarkan kate-gori/kriteria yang dikemukakan oleh Gomez and Yap (1988) dalam Manuputty and Dju-wariah (2009) pada Tabel 1. 
Tabel 1. Kategori Penilaian Tutupan Karang

\begin{tabular}{cc}
\hline $\begin{array}{c}\text { Tutupan } \\
\text { Karang Hidup }\end{array}$ & Kriteria \\
\hline $0-24,9 \%$ & Buruk/Sangat \\
& Rusak \\
$25-49,9 \%$ & Sedang \\
$50-74,9 \%$ & Baik \\
$75-100 \%$ & Sangat baik \\
\hline
\end{tabular}

\section{Analisis Korelasi}

Untuk mengetahui hubungan antara faktor fisik dan kimia perairan dengan persentase tutupan karang maka dilakukan uji korelasi dengan menggunakan software SPSS Ver. 16. Sarwono (2006) dalam Nababan (2009), mengemukakan bahwa koefisien korelasi adalah pengukuran statistik kovarian atau asosiasi an-tara dua variabel. Besarnya koefisien korelasi berkisar antara +1 sampai -1 . Koefisien ko-relasi menunjukkan kekuatan hubungan linear dan arah hubungan dua variabel acak.

Formulasi uji korelasi (Steel dan Torrie, 1991), sebagai berikut:

$$
r=\frac{\sum(\mathrm{x}-\overline{\mathrm{x}})(\mathrm{y}-\overline{\mathrm{y}}) /(\mathrm{n}-1)}{\frac{\sqrt{\sum(\mathrm{x}-\overline{\mathrm{x}})^{2}}}{(\mathrm{n}-1)} \frac{\sqrt{\sum(\mathrm{y}-\overline{\mathrm{y}})^{2}}}{(\mathrm{n}-1)}}
$$

Keterangan:

$$
\mathrm{r}=\text { koefisien korelasi }
$$

$\mathrm{x}=$ parameter fisik dan kimia yang diukur

$\mathrm{y}=$ persentase tutupan karang

$\mathrm{n}=$ jumlah data

Formulasi uji signifikan (Steel dan Torrie, 1991), sebagai berikut:

Keterangan:

$$
t=\frac{r \sqrt{n}-2}{\sqrt{\left(1-r^{2}\right)}}
$$

$\mathrm{t}=$ nilai signifikan

$r=$ koefisien korelasi

$\mathrm{n}=$ jumlah data

Untuk memudahkan melakukan interpretasi mengenai kekuatan hubungan antara dua variabel yaitu parameter fisik dan kimia yang diukur dan persentase tutupan karang (Sarwono, 2006 dalam
Nababan, 2009), dibuat kriteria sebagai berikut:

a. Jika $=0$ : Tidak ada korelasi

b. Jika $>0-0,25$ : Korelasi sangat lemah

c. Jika $>0,25-0,5:$ Korelasi cukup

d. Jika $>0,5-0,75:$ Korelasi kuat

e. Jika >0,75-0,99: Korelasi sangat kuat

f. Jika $=1:$ Korelasi sempurna

\section{HASIL DAN PEMBAHASAN}

Pantai Pasir Putih termasuk dalam wilayah administrasi dari Kelurahan Pasir Putih, Kabupaten Manokwari. Tempat ini merupa-kan lokasi wisata yang terkenal dengan pasir pantai yang putih dan perairan yang teduh dari gelombang karena di lindungi oleh 2 pulau, yakni Pulau Mansinam dan Pulau Lemon. Lokasi wisata ini dapat dicapai dari pusat kota Manokwari selama \pm 15 menit menggunakan kendaraan bermotor. Lokasi penelitian terletak pada lokasi wisata pantai Pasir Putih atau yang oleh masyarakat setempat biasa disebut Pantai Air Salobar. Pantai Air Salobar ini terletak pada sebelah barat daya dari lokasi wisata pantai Pasir Putih.

\section{Kualitas Fisik-Kimia Perairan}

Komponen fisik dan kimia perairan yang diukur adalah kecerahan, temperatur (suhu), salinitas, kecepatan arus, kadar oksigen terlarut (DO), dan derajat keasaman $(\mathrm{pH})$. Komponen parameter tersebut sangat menentukan sebaran dan pertumbuhan dari ekosistem terumbu karang.

\section{Suhu}

Nilai suhu yang diukur pada ketiga Tran-sek pengamatan berkisar antara $27,5-29^{\circ} \mathrm{C}$. Kondisi ini ideal bagi pertumbuhan terumbu karang di Perairan Pasir Putih. Hal ini seperti yang kemukakan oleh Thamrin (2006), bahwa karang hermatipik tumbuh dan berkembang dengan subur pada kisaran suhu antara 25$29^{\circ} \mathrm{C}$.

Mayor (1915) dalam Sudiono (2008) mengemukakan bahwa suhu minimal dan maksimal yang mampu ditolerir terumbu 
ka-rang adalah $16^{\circ} \mathrm{C}$ dan $33,5^{\circ} \mathrm{C}$. Jika suhu perairan berada diluar dari batas tersebut, maka karang dapat kehilangan kemampuan me-nangkap makanan.

\section{Kecerahan Perairan}

Kecerahan perairan yang diukur pada lokasi penelitian saat pengamatan dilakukan adalah $16 \mathrm{~m}$ pada saat perairan tenang. Nilai kecerahan ini sangat ideal bagi pertumbuhan karang, karena nilai kecerahan perairan yang sesuai untuk pertumbuhan karang yang dite-tapkan oleh Kementerian Lingkungan Hidup tahun 2004 adalah > $5 \mathrm{~m}$.

Kondisi kecerahan pada perairan Pasir Putih dapat mendukung pertumbuhan karang dengan baik, karena cahaya dapat masuk ke dasar perairan sampai kedalaman $16 \mathrm{~m}$. Hal ini mendukung zooxanthellae yang bersimbiosis dengan hewan karang untuk melakukan fotosintesis dengan baik.

\section{Kecepatan Arus}

Kecepatan arus dari lima kali pengulangan diperoleh rata-rata kecepatan arus adalah $0,08 \mathrm{~m} / \mathrm{s}$. Nilai ini tergolong baik bagi pertumbuhan terumbu karang. Hal ini sesuai pernyataan Suharsono (1991), kisaran arus yang optimal bagi terumbu karang adalah $0,05-0,08 \mathrm{~m} / \mathrm{s}$.

Pergerakan air atau arus air sangat ber-pengaruh bagi pertumbuhan karang, karena pergerakan air bagi organisme perairan adalah hubungan dengan penyediaan oksigen dan makanan. Bagi karang penyuplai nutrien ter-besar berasal dari simbionnya zooxanthellae. Namun pergerakan arus diperlukan karang dalam memperoleh makanan dalam bentuk plankton dan oksigen serta dalam member-sihkan endapan yang berada di permukaan karang (Harahap, 2004).

\section{Oksigen Terlarut (Dissolved Oxygen)}

Nilai oksigen terlarut yang diukur pada ketiga Transek pengamatan adalah berkisar antara 5,08-5,2 ppm. Oksigen terlarut di perai-ran Pasir Putih ini masih ideal bagi pertum-buhan karang seperti yang dikemukakan oleh Dai (1991) dalam
Edward dan Tarigan (2003), bahwa kadar oksigen dimana terumbu karang tumbuh dan berkembang dengan baik adalah berkisar antara 4,27-7,14 ppm.

Banyaknya oksigen terlarut melalui udara ke air tergantung pada luas permukaan air, suhu, dan salinitas air. Oksigen yang terlarut berasal dari proses fotosintesis tumbuhan dan tergantung pada kerapatan tumbuh-tumbuhan air dan cahaya yang sampai ke badan air tersebut. Kenaikan suhu pada perairan dapat menyebabkan penurunan kadar oksigen ter-larut (Barus, 2004 dalam Nababan, 2009).

\section{Derajat Keasaman (pH)}

Nilai derajat keasaman yang diukur pada ketiga Transek berkisar antara 7,037,15 . Nilai ini masih dapat dikatakan baik bagi pertumbuhan karang, karena masih termasuk dalam kisaran yang ditetapkan oleh Kemen-terian Lingkungan Hidup, yakni 7-8,5 (Kep Men LH No.51 Tahun 2004).

Derajat keasaman $(\mathrm{pH})$ air menggambarkan konsentrasi ion hidrogen dalam suatu perairan. $\mathrm{pH}$ berkaitan erat dengan karbondioksida dan alkalinitas. Semakin tinggi nilai $\mathrm{pH}$ semakin tinggi pula nilai alkalinitas dan sebaliknya semakin rendah kadar karbondioksida bebas (Effendi, 2001 dalam Arsyad, 2006).

\section{Salinitas}

Nilai salinitas yang diperoleh pada ketiga Transek adalah berkisar antara 30$31 \%$. Nilai ini sesuai untuk terumbu karang dapat tumbuh dengan baik seperti yang dikemukakan oleh Dahuri (2003) dalam Pasanea (2013) yakni, 30-35 \%o.

Salinitas di suatu perairan sangat menentukan penyebaran dari terumbu karang. Terumbu karang hanya dapat tumbuh pada tempat dengan kondisi salinitas yang sesuai dengan kriterianya. Meskipun terumbu karang mampu bertahan pada salinitas diluar kisaran tersebut, pertumbuhannya menjadi kurang baik bila dibandingkan pada salinitas normal. 


\section{Persentase Tutupan Karang}

Penutupan karang hidup di Perairan Pasir Putih pada Transek I adalah 91\%, Transek II adalah 78\% dan Transek III adalah 54\%. Tutupan karang hidup tertinggi terjadi pada Transek I dan terendah pada Transek III. Berdasarkan kategori penilaian kondisi eko-sistem terumbu karang oleh Gomez and Yap (1988) dalam Manuputty and Djuwariah (2009), maka terumbu karang di Perairan Pasir Putih berada dalam kondisi baik hingga tingkatan sangat baik. Kondisi sangat baik terdapat pada Transek I dan II, sedangkan kondisi baik terdapat pada Transek II.

Komponen abiotik yang terdiri dari pasir (sand), patahan karang (rubble) dan karang mati (death coral) didapatkan persentase penutupannya berkisar $9-45 \%$. Penutupan ter-tinggi ditemukan pada Transek III dan terendah pada Transek I. Tingginya komponen abiotik dikarenakan kondisi lokasi penelitian yang berdekatan dengan pemukiman pendu-duk, sehingga mudah dipengaruhi oleh adanya aktivitas masyarakat. Di antaranya adalah nelayan pancing yang membuang jangkar pada daerah terumbu karang sehingga mematahkan karang.

Komponen biotik hanya terdiri dari sponge yang ditemukan pada Transek III $(10 \mathrm{~m})$ dengan persentase tutupannya $1 \%$. Zea (1993) dalam Subagio dan Aunurohim (2013) mengemukakan bahwa keberadaan sponge pada perairan yang lebih dalam berhubungan de-ngan interaksinya terhadap organisme terumbu karang lain. Keberadaan organisme hard coral akan terbatasi oleh penetrasi cahaya yang masuk dalam badan perairan. Berkurangnya kelimpahan kelompok hewan hard coral akan meningkatkan kelimpahan organisme sponge laut mengingat berkurangnya hard coral akan berpotensi menambah ruang hidup bagi sponge laut.

Tabel 2. Persentase Tutupan Karang Berdasarkan Kedalaman

\begin{tabular}{llccc}
\hline \multirow{2}{*}{ No } & \multicolumn{1}{c}{ Komponen } & \multicolumn{3}{c}{ Persentase Tutupan (\%) } \\
\cline { 2 - 5 } & & Transek I & Transek II & Transek III \\
\hline $\mathbf{1}$ & Karang Hidup (Live Coral) & 91 & 78 & 54 \\
$\mathbf{2}$ & Biotik Non Karang & & & \\
& -Sponge & 0 & 0 & 1 \\
$\mathbf{3}$ & Abiotik & & & 20 \\
& -Sand & 9 & 18 & 9 \\
& -Death Coral & 0 & 2 & 16 \\
& -Rubble & 0 & 2 & 100 \\
& JUMLAH & 100 & 100 & \\
\hline
\end{tabular}

\section{Persentase Tutupan Karang Transek I}

Berdasarkan pengamatan pada Transek I diletakkan pada kedalaman $3 \mathrm{~m}$, didapatkan persen tutupan karang hidup yang didominasi oleh Non-Acropora yaitu Coral branching (CB), Coral massive (CM) dan Coral encrusting (CE) serta tiga bentuk pertumbuhan dari Acropora, yakni Acropora branching (ACB), Acropora submassive (ACS) dan Acropora encrusting (ACE). Total persentase tutupan karang hidup yang ditemukan pada lokasi pengamatan adalah $91 \%$ dengan kategori sangat baik. 


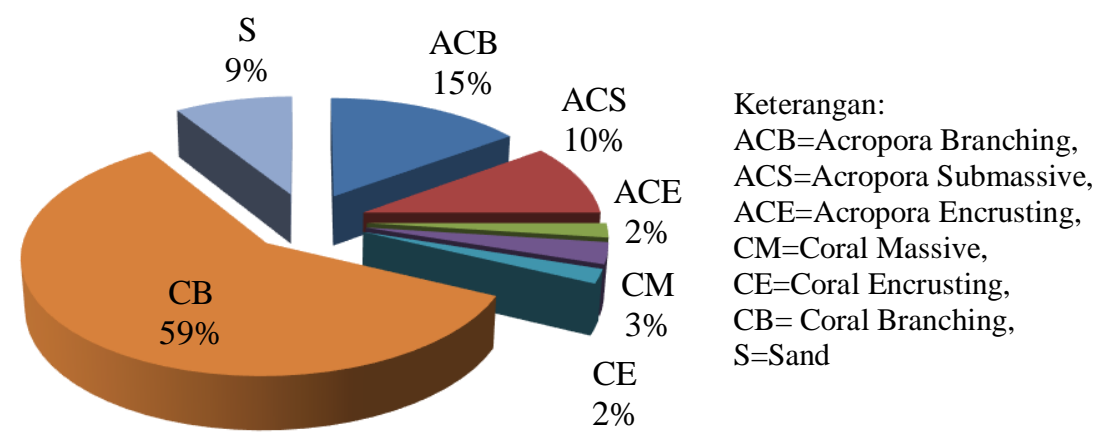

Gambar 2. Diagram Persentase Tutupan Karang pada Transek I

Presentase tutupan karang pada Transek I didominasi oleh bentuk partumbuhan Coral branching, yakni 59\%. Bentuk pertumbuhan Coral branching yang ditemukan, didominasi oleh karang dari spesies Montipora digitata dan Psammocora contigua. Bentuk pertumbuhan lain yang ditemukan dominan adalah Acropora branching (15\%). Dominannya karang jenis ini disebabkan oleh perairan Pasir Putih merupakan perairan yang tenang sehingga memungkinkan karang bercabang untuk tumbuh dengan baik. Hal ini seperti yang dikemukakan oleh Suryanti et al (2011), bahwa terumbu karang yang hidup di daerah terlindung dari gelombang memiliki bentuk pertumbuhan bercabang.

\section{Persentase Tutupan Karang Transek II}

Persentase tutupan karang hidup pada Transek II yang diletakkan pada kedalaman $7 \mathrm{~m}$, didominasi oleh karang jenis NonAcro-pora yaitu Coral encrusting (CE), Coral branching (CB), Coral massive (CM) dan Coral Mushroom (CMR) serta tiga bentuk pertumbuhan lainnya dari jenis Acropora, yakni Acropora branching (ACB), Acropora submassive (ACS) dan Acropora digitate (ACD). Total persentase tutupan karang hidup yang ditemukan pada lokasi pengamatan adalah $78 \%$ dengan kategori sangat baik. Tingginya persentase tutupan karang diduga disebabkan karena Pasir Putih memiliki perairan dengan kualitas fisik dan kimia yang sangat menunjang pertumbuhan karang.

Persentase tutupan karang hidup pada Transek II meskipun masih sangat baik, tetapi persentase tutupan ini lebih kecil jika diban-dingkan dengan persentase tutupan karang pada Transek I. Hal ini dapat disebabkan kurangnya pembersihan endapan pasir atau-pun sampah oleh gelombang pada kedalaman $7 \mathrm{~m}$. Seperti yang dikemukakan oleh Nybakken (1992) bahwa gelombang berfungsi menghalangi pengendapan pada koloni. Meski-pun berada pada daerah terlindung perairan Pasir Putih sesekali diterpa gelombang.

Tingginya persentase tutupan Coral encrusting (28\%) pada Transek II, dapat dise-babkan oleh karang yang beradaptasi terhadap berkurangnya penetrasi cahaya matahari. Hal ini seperti yang dikemukakan oleh Manuputty (1998) bahwa, karang memperlebar koralitnya atau memperlebar permukaan koloninya adalah salah satu strategi untuk memperoleh lebih banyak cahaya matahari. Sedangkan tingginya persentase Coral branching, yakni $25 \%$ dan Acropora branching, yakni $7 \%$, disebabkan karena terumbu karang pada Transek II tersebut berada pada lereng terumbu. Hal ini seperti yang dikemukakan oleh Suryanti et al (2011), 
bahwa terumbu karang yang biasanya hidup pada lereng terumbu umumnya ditumbuhi

bercabang.
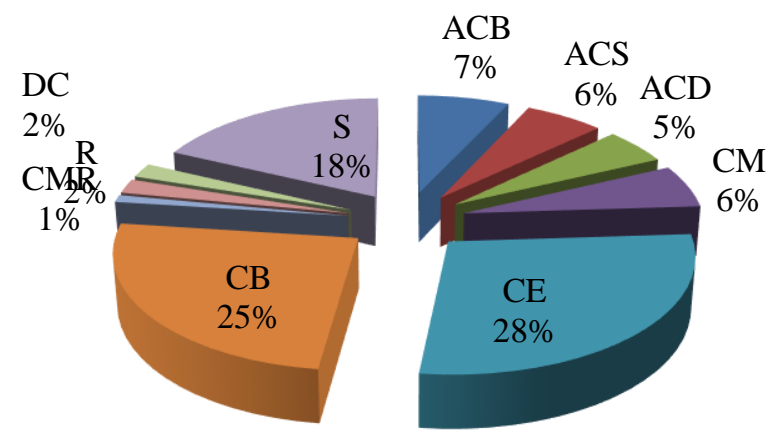

\author{
Keterangan: \\ $\mathrm{ACB}=$ Acropora Branching, \\ ACS=Acropora Submassive, \\ $\mathrm{ACD}=$ Acropora Digitae \\ $\mathrm{CM}=$ Coral Massive, \\ $\mathrm{CE}=$ Coral Encrusting, \\ $\mathrm{CMR}=$ Coral Mushroom, \\ $\mathrm{S}=$ Sand \\ $\mathrm{R}=$ Rubble
}

Gambar 3. Diagram Persentase Tutupan Karang pada Transek II

\section{Persentase Tutupan Karang Transek III}

Persentase tutupan karang hidup pada Transek III yang diletakkan pada kedalaman $10 \mathrm{~m}$, didominasi oleh karang jenis Non-Acro-pora yaitu Coral branching (CB), Coral encrusting (CE) dan Coral massive $(\mathrm{CM})$ serta tiga bentuk pertumbuhan lainnya dari Acropora, yakni Acropora branching (ACB), Acropora submassive (ACS) dan Acropora tabulate (ACT). Total persentase tutupan ka-rang hidup yang ditemukan pada lokasi pengamatan adalah 54\% dengan kategori baik.

Persentase tutupan karang pada Transek III meskipun masih dalam kategori baik, tetapi persentase tutupan ini jauh lebih kecil jika dibandingkan dengan persentase tutupan ka-rang pada Transek I dan II. Hal ini diduga disebabkan kurangnya pembersihan endapan pasir ataupun sampah oleh gelombang pada kedalaman $10 \mathrm{~m}$. Pengaruh gelombang terhadap pembersihan endapan di terumbu karang telah dijelaskan Nybakken (1992) untuk menghalangi terjadinya endapan. Keberadaan sponge pada Transek III juga diduga menjadi penyebab berkurangnya tutupan karang pada kedalaman tersebut. Seperti yang dikemukakan oleh Sheppard (1982) bahwa sponge dapat menghambat pertumbuhan karang bahkan dapat membunuh karang, karena sponge yang hidup pada jaringan karang dapat menyerap nutrisi dari jaringan karang tersebut. Disebutkan juga bahwa sponge akan bertumbuh lebih cepat pada karang mati.

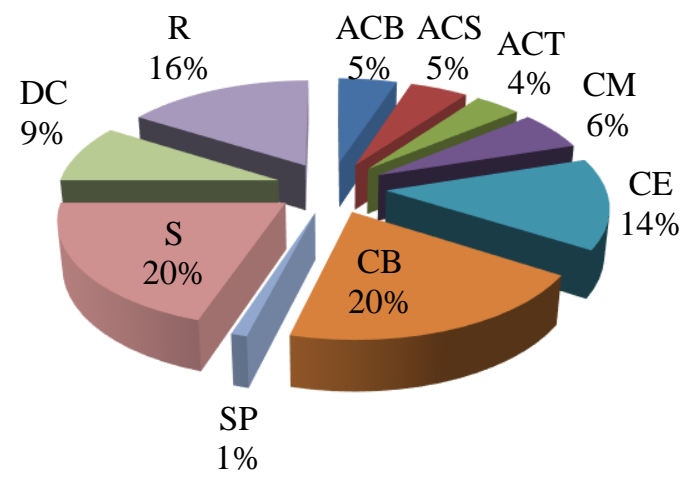

\author{
Keterangan: \\ $\mathrm{ACB}=$ Acropora Branching, \\ $\mathrm{ACS}=$ Acropora Submassive, \\ ACT $=$ Acropora Tabulate \\ $\mathrm{CM}=$ Coral Massive, \\ $\mathrm{CE}=$ Coral Encrusting, \\ $\mathrm{CB}=$ Coral Branching, \\ $\mathrm{SP}=$ Sponge \\ $\mathrm{S}=$ Sand \\ $\mathrm{R}=$ Rubble
}

Gambar 4. Diagram Persentase Tutupan Karang pada Transek III 
Aktivitas masyarakat yang memancing pada daerah terumbu karang yang terlihat pada saat penelitian dilakukan, dapat berpengaruh pada tingginya persentase tutupan patahan karang (rubble) (16\%) di Transek III. Nelayan yang berlabuh untuk memancing, melepaskan jangkar atau sauh perahu mereka pada daerah terumbu karang secara langsung dapat mema-tahkan atau merusak karang.

Tingginya persentase tutupan Coral branching (20\%) dan Coral encrusting (14\%) pada Transek III masih sama seperti yang dibahas pada tutupan Coral branching dan Coral encrusting pada Transek II. Pada karang jenis Coral branching, terumbu karang tersebut berada pada lereng terumbu, sehingga umumnya ditumbuhi oleh jenis karang-karang bercabang. Sedangkan pada Coral encrustting dapat disebabkan oleh mulai berkurangnya penetrasi cahaya matahari, sehingga karang memperlebar koralitnya atau memperlebar permukaan koloninya untuk memperoleh le-bih banyak cahaya matahari.

\section{Pengaruh Parameter Fisik dan Kimia Perairan terhadap Persentase Tutupan Terumbu Karang}

Hasil uji analisis menunjukkan bahwa suhu perairan di Pasir Putih memiliki korelasi sempurna (1) dengan persentase tutupan karang dengan nilai signifikan adalah 0,01 atau secara statistik selang kepercayaan adalah $99 \%$. Sedangkan oksigen terlarut dan kedala-man perairan memiliki korelasi yang tidak searah $(-1)$ terhadap persentase tutupan karang. Oksigen terlarut dan kedalaman perairan memiliki nilai signifikan 0,01 (selang keper-cayaan 99\%), artinya kedua parameter ini memberikan pengaruh yang nyata untuk per-sentase tutupan karang.

Suhu perairan memiliki korelasi yang sempurna (sangat signifikan) atau sangat searah dengan persentase tutupan karang. Artinya persentase tutupan karang akan bertambah seiring dengan kondisi suhu atau temperatur perairan. Hal ini disebabkan suhu perairan me-rupakan salah satu faktor yang sangat mempengaruhi persentase tutupan karang. Seper- ti yang dikemukakan oleh Mayor (1995) dalam Mulya (2006) bahwa suhu berpengaruh terhadap tingkah laku makan hewan karang, demikian juga pertumbuhannya.

Kondisi oksigen terlarut memiliki korelasi yang tidak searah dengan persentase tutupan karang. Ini berarti bahwa persentase tutupan karang dipengaruhi oleh tinggi-rendahnya oksigen terlarut pada hasil penelitian ini. Meskipun demikian, oksigen terlarut merupakan salah satu faktor yang mempengaruhi persentase tutupan karang, karena terumbu karang membutuhkan oksigen terlarut untuk metabolismenya. Namun sebaran oksigen terlarut di perairan lebih bergantung pada tinggi-rendahnya nilai suhu perairan. Suhu perairan yang tinggi akan menyebabkan oksigen terlarut menjadi rendah karena oksigen akan terlepas atau menguap ke udara jika mengalami pemanasan. Seperti yang dijelaskan oleh Effendi (2003) bahwa hubungan antara kadar oksigen terlarut dan suhu menggambarkan bahwa semakin tinggi suhu, maka kelarutan oksigen akan semakin berkurang.

Hasil analisis korelasi juga menunjukkan bahwa kedalaman perairan di Pasir Putih me-miliki arah hubungan yang tidak searah dengan persentase tutupan karang. Artinya jika kedalaman bertambah maka persentase tutupan karang akan berkurang. Kondisi ini terkait dengan kehidupan alga zooxanthellae yang bersimbiosis dengan hewan karang. Alga ini membutuhkan cahaya matahari untuk melakukan fotosintesis. Jika kedalaman bertambah maka, penetrasi cahaya matahari akan semakin berkurang. Hal inilah yang menyebabkan persentase tutupan karang akan semakin berkurang seiring bertambahnya kedalaman. Seperti yang dijelaskan oleh Hutabarat dan Evans (1984) dalam Pasanea (2013) bahwa terumbu karang memerlukan cahaya matahari agar zooxanthellae yang bersimbiosis dengan karang dapat melakukan fotosintesis. 


\section{Ancaman terhadap Keberadaan Terum- bu Karang di Perairan Pasir Putih}

Ancaman yang dihadapi oleh terumbu karang pada perairan Pasir Putih, dapat dike-lompokkan menjadi 2, kegiatan manusia dan factor alam.

\section{Kegiatan manusia (anthrophogenic cau- ses)}

Aktivitas wisatawan yang berenang di sekitar daerah terumbu karang dan menginjak karang adalah salah satu contoh kegiatan manusia yang mengancam keberlangsungan ekosistem terumbu karang. Banyaknya sampah yang dihasilkan oleh para wisatawan selain dapat mengurangi nilai estetika juga dapat merusak ekosistem terumbu karang, karena dapat menghalangi fotosintesis tumbuhan zooxanthellae yang bersimbiosis dengan hewan karang. Selain itu, aktivitas nelayan yang memancing pada daerah terumbu karang yang kebetulan ditemukan pada saat pengambilan data, juga merupakan salah satu penyebab rusaknya terumbu karang. Nelayan yang ber-labuh untuk memancing, melepaskan jangkar atau sauh perahu mereka pada daerah terumbu karang yang secara langsung dapat mema-tahkan karang. Hal ini seperti yang dinyatakan oleh Monk et al, (2000) dalam Mulya (2006), bahwa dampak negatif yang ditimbulkan langsung oleh manusia adalah pembuangan sampah, teknik penangkapan ikan yang merusak dan kegiatan parawisata yang tidak diawasi.

\section{Faktor Alam (natural causes)}

Salah satu faktor alam dapat mengancam keberlangsungan ekosistem terumbu karang adalah bintang laut berduri (Acanthaster plan-ci). Disebutkan dapat mengancam terumbu karang, karena hewan ini adalah salah satu predator alami bagi polip karang hidup. Belum ada penelitian mengenai kepadatan $A$. planci di perairan Pasir Putih, sehingga belum diketa-hui jumlah yang pasti mengenai kepada-tannya. Azis (1995) dalam Iksan et al, (2013), mengemukakan bahwa jika populasi A. planci lebih dari 14 individu/ $1000 \mathrm{~m}^{2}$, maka keberadaannya sudah mengancam terumbu karang. Artinya jika jumlah $A$. planci dibawah nilai tersebut, belum dianggap berbahaya untuk da-pat merusak komunitas karang.

\section{Pengelolaan Terumbu Karang di Perai- ran Pasir Putih}

Hasil penelitian ini memberikan informasi mengenai persentase tutupan terumbu karang di perairan Pasir Putih, sehingga untuk menindaklanjutinya perlu dilakukan langkah-langkah pengelolaan sumberdaya dan pengembangannya untuk pemanfaatan yang optimal. Selain Pasir Putih yang memang sudah dikenal sebagai tujuan wisata pantai di kota Manokwari, beberapa informasi terkait per-syaratan wisata terumbu karang diperoleh dari hasil penelitian ini untuk peningkatan dan pe-ngembangan pemanfaatan sumberdaya. Yulianda (2007) dalam Adi et al (2013) me-nyebutkan bahwa kesesuaian suatu lokasi untuk dijadikan wisata diving harus meme-nuhi 6 komponen yaitu kecerahan perairan, tutupan karang, jumlah lifeform, jenis ikan karang, kedalaman dan arus, sedangkan untuk wisata snorkeling perlu 7 komponen terdiri dari 6 komponen yang telah disebutkan ditambah 1 komponen yaitu lebar hamparan karang.

Berdasarkan pengamatan terhadap aktifitas masyarakat, hasil penelitian terhadap persentase tutupan karang di perairan Pasir Putih, dan penelusuran dokumen terkait pengelolaan sumberdaya di Kabupaten Manokwari, maka perlu dilakukan upaya pengelolaan sumber-daya perairan ini. Upaya yang dapat dilakukan untuk pemanfaatan dan pengelolaan sumberdaya terumbu karang di perairan Pasir Putih, diantaranya:

\section{Pengelolaan Sumberdaya Ekosistem Terumbu Karang Berbasis Masyara- kat}

Masyarakat sekitar Pasir Putih sampai saat ini hanya terlibat dalam pemungutan iuran (retribusi) masuk ke lokasi wisata, dan pembersihan pesisir 
pantai bekerjasama dengan Kelurahan dan Dinas Pariwisata. Pemanfaatan terumbu karang di perairan Pasir Putih serta perencanaan pembangunan di sekitar Kelurahan Pasir Putih perlu memperhatikan kelestarian lingkungan pesisir sehingga tidak merusak terumbu karang yang kondisinya masih sangat baik. Keikutsertaan masyarakat dalam pengelolaan sumberdaya yang ada di lingkungannya akan menumbuhkan rasa tanggung jawab untuk berpartisipasi dalam menjaga terumbu karang dari kerusakan.

Kegiatan penyuluhan mengenai kesadaran akan fungsi dan manfaat terumbu karang baik secara ekologis maupun ekono-mis kepada masyarakat setempat, kedepannya perlu dilakukan. Selain itu, hal-hal seperti menginjak karang, membuang jangkar pada daerah terumbu karang dan membuang sampah ke laut juga harus disampaikan kepada masyarakat yang tinggal di wilayah pesisir, karena hal-hal tersebut dapat merusak terumbu karang.

\section{Koordinasi pemerintah dengan masya-rakat}

Koordinasi antara pemerintah dengan masyarakat dapat menjadi kekuatan untuk pengelolaan dan pengawasan sumberdaya perairan, serta pemecahan konflik yang mungkin bisa muncul. Pada saat ini, upaya pemerintah daerah Kabupaten Manokwari melalui Dinas Pariwisata Kabupaten Manokwari telah membuat RTRW dan Master Plan berupa perencanaan kawasan wisata untuk perairan Pasir Putih (Dinas Kebudayaan dan Pariwisata Ka-bupaten Manokwari, 2015).

Meletakkan papan informasi ataupun pe-ngumuman merupakan hal lainnya yang dapat dilakukan. Papan informasi tersebut dapat be-risi himbauan maupun peringatan untuk memberikan kesadaran menjaga terumbu karang bagi masyarakat dan menampikan program-program untuk menjaga terumbu karang. Pemerintah daerah juga perlu mendorong, membantu dan memotivasi kegiatan masyarakat untuk melestarikan terumbu karang, dan dapat membantu masyarakat untuk mengembangkan alternatif mata pencaharian dengan memberikan pelatihan seperti membuat bahan kerajinan tangan, sebagai bagian dari kegiatan wisata.

\section{Pengawasan dan Rehabilitasi Terumbu Karang}

Pengawasan terumbu karang di perairan Pasir Putih secara berkelanjutan perlu melibatkan masyarakat dan pemerintah (instansi terkait), agar keindahan terumbu karang tetap terjaga. Upaya rehabilitasi atau pemulihan karang yaitu memperbaiki kondisi terumbu karang yang telah rusak dengan mengurangi aktivitas masyarakat di lokasi terumbu karang.

Salah satu bentuk rehabilitasi untuk mengembangkan dan menjaga keanekaragaman terumbu karang yakni melalui trans-plantasi karang, yaitu pencangkokan atau pemotongan karang hidup yang ditanam di tempat yang telah mengalami kerusakan. Jika terumbu karang di lokasi ini tetap terjaga de-ngan baik akan menyediakan stok ikan di sekitar perairan Pasir Putih. Selain itu, untuk mengurangi laju degradasi terumbu karang, maka perlu dilakukan upaya untuk mencegah terjadinya pencemaran sampah dan bahan pencemar lainnya yang bersumber dari darat.

\section{KESIMPULAN}

Berdasarkan hasil yang diperoleh, dapat disimpulkan bahwa:

1. Persentase tutupan karang pada Transek 1 adalah 91\% (sangat baik), Transek II adalah 78\% (sangat baik) dan Transek III adalah 54\% (baik).

2. Kualitas fisik kimia perairan air di lokasi penelitian meliputi suhu 27,5$29^{\circ} \mathrm{C}$, oksi-gen terlarut 5,08-5,2 ppm, pH 7,03-7,15, salinitas 30-31\%, kecepatan arus $0,08 \mathrm{~m} / \mathrm{s}$ dan kecerahan perairan $16 \mathrm{~m}$. Nilai-nilai kualitas air ini ideal bagi pertumbuhan te-rumbu karang. Parameter kualitas air yang paling berpengaruh atau sangat signifikan terhadap persentase tutupan karang ber-dasarkan hasil uji korelasi 
adalah suhu, oksigen terlarut dan kedalaman perairan.

\section{DAFTAR PUSTAKA}

Adi A B, A Mustafa dan R Ketjulan. 2013. Kajian Potensi Kawasan dan Kesesuaian Ekosistem Terumbu Karang di Pulau Lara Untuk Pengembangan Eko-wisata Bahari. Jurnal Mina Laut Indonesia, Vol 1(1); 4960.

Arsyad M. 2006. Analisis Tingkat Pencemaran Dengan Pendekatan Plankton Sebagai Bioindikator Di Perairan Teluk Doreri Manokwari. Skripsi Jurusan Perikanan, Fakultas Peternakan Perikanan dan Ilmu Kelautan, Universitas Negeri Papua, Manokwari.

Burhanuddin A I, H M N Nessa dan A Niartiningsih. 2013. Membangun Sumber Daya Kelautan Indonesia Gagasan dan Pemikiran Guru Besar Universitas Hassanudin. IPB Press; Bogor.

Dinas Kebudayaan dan Periwisata Kabupaten Manokwari. 2015. Program Pengembangan Kawasan Wisata Terpadu Pantai Pasir Putih. (Diakses 8 Januari 2015 melalui http://pariwisata-manokwari.blogspot.com/p/programunggulan.html).

Edward dan Tarigan Z. 2003. Pemantauan Kondisi Hidrologi Di Perairan Raha P. Muna Sulawesi Tenggara Dalam Kai-tannya Dengan Kondisi Terumbu Karang. Jurnal Makara Sains, Vol. 7 (2); 73-82.

Effendi H. 2003. Telaah Kualitas Air bagi Pengelolaan Sumber Daya dan Lingku-ngan Perairan. Cetakan Kelima. Penerbit Kanisius, Yogyakarta.

English S, C Wilkinson and V Baker. 1994. Survey Manual For Tropical Marine Resources. ASEAN-Australia Marine Science Project: Living Coastal Resources.

Harahap K A. 2004. Kondisi Ekosistem Terumbu Karang di Perairan Sekitar Pu-lau Batam, Riau. Skripsi
Departemen Ilmu dan Teknologi Kelautan Fakultas Perikanan dan Ilmu Kelautan Institut Pertanian Bogor.

Hill $\mathrm{J}$ and C Wilkinson. 2004. Methods For Ecological Monitoring of Coral Reefs. A Resource For Managers. Australian Institute of Marine Science, Towns-ville, Australia.

Ikhsan N, B Sadarun dan R Ketjulan. 2013. Kelimpahan Acanthaster plancii pada Perairan Terumbu Karang di Pulau Bero, Selat Tiworo, Kabupaten Muna, Sulawesi Tenggara. Jurnal Mina Laut Indonesia, Vol 2(6); 59-68.

Keputusan Menteri Negara Lingkungan Hidup Nomor 51 Tahun 2004. Tentang Baku Mutu Air Laut.

Manuputty A E W and Djuwariah. 2009. Method Guide Point Intercept Transect (PIT) for Community Baseline Study and Coral Health Monitoring at Marine No Take Zone Area (DPL). Coral Reef Rehabilitation and Management Prog-ram Indonesian Institute of Science COREMAP II-LIPI; Jakarta.

Manuputty A E W. 1998. Sebaran Vertikal Karang Batu dan Pertumbuhannya di Pulau Pari, PulauPulau Seribu. Pusat Penelitian dan Pengembangan Oseanologi, Lembaga Ilmu Pengetahuan Indonesia. Jakarta.

Mulya M B. 2006. Kondisi Terumbu Karang Berdasarkan Persen Tutupan di Pulau Karang Provinsi Sumatea Utara dan Hubungannya dengan Kualitas Perai-ran. Jurnal Komunikasi Penelitian, Vol 18 (2); 1-6.

Nababan T M. 2009. Persen Tutupan (Percent Cover) Terumbu Karang di Bagian Timur Perairan Pulau Rubiah Nanggroe Aceh Darussalam. Skripsi Departemen Biologi Fakultas Matematika dan Ilmu Pengetahuan Alam Universitas Suma-tera Utara. 
Nybakken J W. 1992. Biologi Laut; Suatu Pendekatan Ekologis. Penerbit Gramedia. Jakarta.

Pasanea Y E. 2013. Kondisi Terumbu Karang Dan Penyusunan Konsep Strategis Pengawasan Ekosistem Terumbu Ka-rang Di Pulau Mansinam Kabupaten Manokwari. Skripsi Jurusan Ilmu Ke-lautan, Fakultas Ilmu Kelautan Dan Perikanan, Universitas Hasanuddin, Makassar.

Sheppard C R C. 1982. Coral Populations On Reef Slope And Their Major Controls. Marine Ecology Progress Series. Vol 7: 83-115.

Steel R G D dan Torrie. 1991. Prinsip dan Prosedur Statistika; Suatu Pendekatan Biometrik. Gramedia Pustaka Utama; Jakarta.

Subagio I B dan Aunurohim. 2013. Struktur Komunitas Spons Laut (Porifera) Di Pantai Pasir Putih, Situbondo. Jurnal Sains dan Seni Pomits Vol 2(2); 159-165

Sudiono G. 2008. Analisis Pengelolaan Terumbu Karang Pada Kawasan Konservasi Laut Daerah (KKLD) Pulau Randayan dan Sekitarnya Kabupaten Bengkayang Provinsi Kalimantan Barat. Tesis. Program Magister Ilmu Lingkungan, Universitas Diponegoro, Semarang.

Suharsono. 1995. Metode penelitian terumbu karang. Kursus Pelatihan Metodologi Penelitian Penentuan Kondisi Terumbu Karang. Jakarta: Pusat Penelitian dan Pengembangan Oseanologi-LIPI.

Suryanti, Supriharyono dan Y Roslinawati. 2011. Pengaruh Kedalaman Terhadap Morfologi Karang Di Pulau Cemara Kecil, Taman Nasional Karimunjawa. Jurnal Saintek Perikanan Vol 7 (1): 63-69.

Thamrin. 2006. Karang : Biologi Reproduksi \& Ekologi. Mina Mandiri Pres: Pekanbaru.

Veron, J. E. N., 2000a. Corals of The World. Volume 1. Australian Institute of Marine Science and CRR Qld Pty Ltd Publisher. Townsville. Australia.
Veron, J. E. N., 2000b. Corals of The World. Volume 2. Australian Institute of Marine Science and CRR Qld Pty Ltd Publisher. Townsville. Australia.

Veron, J. E. N., 2000c. Corals of The World. Volume 3. Australian Institute of Marine Science and CRR Qld Pty Ltd Publisher. Townsville. Australia. 
